\title{
PEMAKAIAN AKROLEK PADA TUTURAN ASERTIF DALAM GELAR WICARA HITAM PUTIH
}

\author{
Bawon Wiji Dia Prasasti ${ }^{1}$ dan Gigit Mujianto \\ ${ }^{1}$ Universitas Muhammadiyah Malang: wijidiaprasasti.03@gmail.com \\ ${ }^{2}$ Universitas Muhammadiyah Malang: gigit@umm.ac.id
}

Artikel Info

Kata Kunci: akrolek, Penelitian ini bertujuan untuk mendeskripsikan pemakaian tuturan asertif, gelar akrolek pada fungsi tuturan asertif presenter dan wicara narasumber dalam gelar wicara Hitam Putih di situs daring youtube edisi $1-4$ pada tahun $2017-2020$. Tujuan khusus penelitian berupa mendeskripsikan fungsi tuturan asertif presenter dan narasumber dalam acara gelar wicara Hitam Putih. Teori variasi akrolek berpegang pada teori yang dikemukakan oleh Searle dan Lonie Agustin dan Teori yang dijadikan acuan pada tuturan asertif yang dijadikan pegangan dalam penelitian ini yaitu teori Searle. Penelitian ini menggunakan pendekatan deskriptif. Jenis penelitian ini adalah kualitatif. Metode yang digunakan dalam penelitian ini adalah analisis deskriptif. Sumber data penelitian adalah acara gelar wicara youtube Hitam Putih Trans7 Official. Data dalam penelitian ini berupa tuturan asertif presenter dan narasumber. Analisis data menggunakan model Alir dengan tiga tahapan kegiatan yakni, pengumpulan data, menyeleksi data, penjelasan data, dan pengambilan kesimpulan. Hasil penelitian menunjukkan para peserta didik menggunakan fungsi asertif berupa: (1) tindak tutur asertif menyatakan, (2) tindak tutur asertif membual, (3) tindak tutur asertif menyarankan, (4) tndak tutur asertif mengeluh, dan (5) tindak tutur asertif membanggakan.

\section{A. PENDAHULUAN}

Masyarakat menjadikan bahasa sebagai alat atau sarana berkomunikasi pada kegiatan berinteraksi dan bersosialisasi dalam kehidupan bersosial. Melalui kegiatan komunikasi tersebut, bahasa senantiasa membantu manusia dalam menyampaikan gagasan dan pandangan dengan penggunaan bahasa yang mudah dimengerti maksud dan maknanya satu sama lain, sehingga terjalin komunikasi yang baik antar sesama. Oleh sebab itu, tanpa bahasa manusia tidak dapat mengungkapkan keinginan dan tujuannya kepada manusia lain. Hal tersebut erat kaitannya dengan fungsi bahasa yang dapat menjamin intensitas komunikasi dalam interaksi sosial Halliday (dalam Tarigan, 2009:6). Oleh karena itu, bahasa ada dalam 
kehidupan agar manusia dapat berinteraksi, mengerti, dan saling belajar melalui tuturan.

Maka dari itu, tuturan menjadi keterampilan mengemukakan suatu informasi melalui bahasa lisan. Melalui tuturan tersebut, terbentuklah suatu aktivitas berupa percakapan. Percakapan merupakan salah satu bentuk dari peristiwa tutur dalam aktivitas sosial karena erat kaitannya dengan pihak yang terlibat dalam kegiatan berkomunikai pada waktu dan peristiwa tertentu. Di dalam peristiwa tutur, penutur selalu menginginkan mitra tutur dapat memahami dan mengerti informasi yang disampaikan penutur. Maka dari itu, penutur dalam kegiatan interaksi komunikasi menggunakan strategi dengan konteks berdasar pada persoalan yang mudah dipahami lawan tutur Wijaya (dalam Apriastuti, 2017:40).

Dalam perananannya, tindak tutur digunakan manusia sebagai wujud mengekpresikan perasaan dan pemikiran berupa gagasan, ide, dan informasi yang diketahui antar-penutur. Tujuan dalam tuturan yang berlangsung pada peristiwa tutur mencakup berbagai jenis tindak tutur, salah satunya tindak tutur asertif.

Menurut Searle (dalam Sari, 2016:18) tindak tutur asertif (assertive) atau representatif (representatives) yaitu penutur dalam proposisi berdasar pada realita atau kebenaran yang diungkapkan. Penggunaan bahasa dalam kegiatan tuturan merupakan suatu kemampuan manusia yang tidak dapat dimiliki oleh makhluk lainnya. Kemampuan penggunaan bahasa menjadikan manusia sebagai makhluk sosial, etika dengan lingkup kebudayaan, dan ilmu pengetahuan guna meningkatkan mutu sebagai pengukur kualitas diri. Pemakaian bahasa dalam kehidupan bukan berarti menggunakan bahasa baku yang baik dan benar seperti yang disarankan pemerintah, melainkan menggunakan bahasa sesuai realita, fungsi, tujuan, serta situasi tertentu dalam kegiatan bertutur (Susilawati, 2017:1). Dilihat dari penggunaan bahasa tersebut, maka dapat diketahui tindak tutur asertif termasuk dalam kategori tindak tutur ilokusi yang melibatkan pembicara dengan kebenaran proposisi yang diujarkan, misalnya: asertif menyatakan, asertif menyarankan, asertif membanggakan, asertif mengeluh, asertif melaporkan, asertif mengklaim, dan asertif membual, pengguanaan ketujuh fungsi ini bergantung pada realita, fungsi, tujuan, dan situasi yang dialami antar-penutur Searle (dalam Chaer, 2014:17).

Masyarakat dalam pemakaian fungsi bahasa tersebut tidak terlepas dari sarana bahasa yang dipakai dalam aktivitas komunikasi. Bidang kajian bahasa yang dipakai kalangan masyarakat berupa varietas dengan fungsi penggunaannya yang disebut sosiolinguistik. Sosiolinguistik merupakan sebuah kajian antara sosio dan ilmu linguistik yang berkenaan dengan seluk beluk bahasa. Fasold (dalam Saddhono, 2006:2-3) mengemukakan bahwa sosiolinguistik berdasar pada dua kenyataan. Pertama, varietas-varietas bahasa berdasar pada pilihan bahasa bagi para penutur. Kedua, bahasa sebagai sarana atau alat menyampaikan perasaan dan pemikiran penutur pada mitra tutur.

Kenyataan tersebut menunjukkan, penggunaan varietas bahasa berkaitan dengan golongan atau komunitas suatu kelompok tertentu berupa perbedaan jenis kelamin, usia, kelas sosial, hubungan antarpenutur, tujuan komunikasi, serta tempat berlangsungnya komunikasi (Mujianto, 2013:14). Tidak hanya itu, penggunaan varietas bahasa mengalami perubahan akibat perubahan zaman. Melalui perkembangan zaman dapat membentuk jenis variasi bahasa baru, salah satunya adalah variasi bahasa akrolek. Menurut Searle dan Agustin (dalam Nuryani, 2016:64) variasi bahasa akrolek merupakan jenis variasi bahasa yang paling tinggi dan bergengsi dibanding varietas bahasa yang lain. Variasi akrolek, biasa digunakan oleh 
kalangan bangsawan, raja kepada abdi mereka, atau masyarakat metropolitan. Hal tersebut sesuai dengan pendapat Suhendar (2016:56) salah satu faktor variasi bahasa akrolek lebih tinggi tingkatannya dengan varietas bahasa yang lain adalah adanya anggapan suatu nilai kesopanan dalam variasi bahasa akrolek tersebut.

Pemakaian variasi akrolek sering terjadi dan digunakan pada kalangan masyarakat dengan situasi formal dan non formal yang dilakukan antar-penutur dalam stasiun televisi di Indonesia yang cukup beragam. Media youtube daring menjadi salah satu media yang banyak ditonton oleh masyarakat. Hal ini dikarenakan media aplikasi youtube juga memberitakan peristiwa politik, gelar wicara, dialog, dan lain sebagainya Soyomukti (2013:6). Salah satunya yaitu program acara Hitam Putih yang tidak hanya ada pada program acara televisi melainkan juga media pada konten youtube daring berupa acara gelar wicara yang menghadirkan para aktor pemerintah, politik, pengusaha, guru, dan kalangan kelas menengah lainnya. Tidak sedikit para aktor atau narasumber yang diundang dalam acara sesuai dengan anggapan dan sumber informasi yang mereka miliki sehingga tuturan yang diucapkan antarpenutur berkaitan erat dengan realita dengan fungsi tindak tutur asertif dengan penggunaan variasi akrolek yang dianggap paling bergengsi dikalangan masyarakat. Hal ini sebagai umpan balik ujaran antarpenutur yaitu tindak tutur langsung dan tindak tutur tidak langsung yang dituturkan.

Dalam pelaksanan komunikasi, setiap individu memakai jenis kalimat dan variasi bahasa yang beraneka garam. Pemakaian jenis tuturan kalimat yang diujarkan memiliki kesesuaian dan ada pula yang tidak sesuai dengan modus kalimat yang diujarkan. Menurut Yule (dalam Tressyalina, 2015:92) dalam kegiatan bertutur terdapat hubungan langsung antara struktur dan fungsi tuturan, hal tersebut disebut dengan tuturan langsung. Namun, jika terdapat hubungan tidak langsung antara struktur dengan fungsi, maka kalimat tersebut mengandung suatu tindak tutur tidak langsung. Berdasar uraian tersebut, tuturan langsung memiliki kesamaan antara bentuk dengan modus pengujarannnya, sedangkan tuturan tidak langsung memiliki perbedaan antara modus dengan dengan bentuk pengujaran yang dipakai oleh penutur.

Berpijak pada uraian di atas, penelitian ini mengambil judul "Pemakaian Akrolek Pada Tuturan Asertif dalam Gelar Wicara Hitam Putih". Berdasar judul tersebut penelitian bertujuan untuk menjelaskan penggunaan variasi akrolek yang dipakai oleh kalangan kelas mengenah ke atas pada fungsi tuturan asertif seperti yang digunakan narasumber dan presenter dalam interaksi gelar wicara Hitam Putih. Fokus penelitian ini mengkaji pemakaian akrolek tuturan asertif dalam interaksi gelar wicara di program acara Hitam Putih. Inti penelitian ini berupa jenis tuturan asertif yang digunakan dalam gelar wicara.

Penelitian ini menarik dilakukan karena diharapkan dapat mengembangkan penelitian bidang ilmu sosiolinguistik mengenai variasi bahasa akrolek melalui penggunaan tuturan asertif. Tidak hanya itu, kajian teori variasi bahasa akrolek dan tuturan asertif sangat relevan jika menggunakan tuturan kelas menengah, karena tuturan yang digunakan oleh kalangan kelas sosial menengah berwujud pada berbagai macam bahasa gaul atau akrolek dan wujud penggunaannya berupa tuturan asertif.

Sejauh peneliti mencermati sumber rujukan, penelitian tentang pemakaian akrolek belum pernah dilakukan oleh peneliti sebelumnya. Berbeda dengan penelitian tuturan asertif yang sudah dilakukan oleh beberapa penelitian. Berikut penelitian yang sudah dilakukan sehingga dapat membantu dalam pengembangan 
penelitian ini. Pertama, hasil penelitian (Arnaselis, 2017) yang berjudul Tindak Tutur Asertif dalam Roman Larasati Karya Pramoedya Ananta Toer dan Implikasinya. Fokus penelitian ini berupa pengimplikasian tuturan asertif dengan pembelajaran bahasa indoensia di SMP. Kedua, penelitian (Novitasari, 2015) berjudul Kesantunan Asertif dalam Bidang Tenaga Kependidikan Universitas Muhammadiyah Surakarta (UMS). Fokus penelitian ini yaitu representasi wujud kesantunan asertif yang digunakan oleh bidang tenaga kependidikan di universitas. Ketiga, tulisan dari (Apriyanti,2017) berjudul Tindak Tutur Asertif Penjual dan Pembeli di Pasar Tempel Rajabasa dan Bandar Lampung serta Implikasinya Pada Pembelajaran Bahasa Indonesia di SMA. Fokus penelitian dalam tulisan ini berupa ekspresi tindak tutur asertif yang digunakan penjual dan pembeli di Pasar Tempel Rajabasa Bandar Lampung dan implikasinya bagi pembelajaran bahasa Indonesia di SMA.

Penelitian ini berbeda dengan penelitian sebelumnya. Pebedaan tersebut terletak pada fokus objek penelitian. Secara keseluruhan, penelitian sebelumnya tentang tuturan aserif, objek penelitiannya adalah novel, tenaga pendidikan, penjual dan pembeli, sedangkan dalam penelitian ini objek penelitiannya yaitu narasumber dan presenter gelar wicara hitam putih.

\section{B. METODE}

Penelitian menggunakan pendekatan deskriptif yaitu mendeskripsikan dan menemukan peran teoritis akrolek pada tuturan asertif presenter dan narasumber dalam gelar wicara. Metode dalam penelitian ini menggunakan deskriptif analisis. Sumber data penelitian berupa acara gelar wicara youtube Hitam Putih Trans7 Official seperti: (1) Kisah Demian Aditya Perform di Amerika. Edisi 4-2 tahun 2017, (2) Viral, Anak Majikan
Memberangkatkan Umroh Pengasuhnya. Edisi 3 tahun 2018, (3) Najwa Shihab: Tamu Istimewa. Edisi 3-4 tahun 2018, (4) Biografi, Rudy Salim Sang Juraga Mobil Lulusan SMA. Edisi 2 tahun 2018, (5) Billy, Anak Penjual Kue Asal Papua yang Jadi Staf Khusus Presiden. Edisi 1 tahun 2019, dan (6) Tri Adinata, Guru Viral Mengajar Gitar Dengan Energik. Edisi 1 tahun 2020.

Teknik pengumpulan data dalam penelitian ini yaitu observasi, partisipan tak langsung, studi dokumen berupa video audio-visual dari media sosial youtube Hitam Putih Trans7 official. Dari beberapa tayangan youtube hitam putih tersebut kemudian dikelompokkan sesuai dengan masing-masing data untuk selanjutnya dianalisis. Proses analisis data dilakukan dengan mengelompokkan transkip berdasar indikator fungsi bahasa tuturan asertif presenter dan narasumber gelar wicara. Berdasarkan penelitian sebelumnya, data dalam penelitian ini dikumpulkan dengan cara transkip data dan digolongkan untuk dianalisis melalui model Allir (Huberman \& Milles, 1992). Analisis data model ini terdiri dari tiga tahapan yakni, (1) mengumpulkan data, (2) pemilihan data, (3) penjelasan data, dan (4) pengambilan kesimpulan.

\section{HASIL DAN PEMBAHASAN}

Fungsi Tindak Tutur Asertif Presenter dan Narasumber dalam Gelar Wicara

\section{Hitam Putih}

Dalam acara gelar wicara hitam putih konten youtube daring program acara yang dari stasiun Trans7 official tahun 20172020. Pemakaian akrolek dalam kegiatan interaksi atau berkomunikasi berupa fungsi tuturan asertif yang dapat dideskripsikan pada data sebagai berikut.

\section{Tindak Tutur Asertif Menyatakan}

Tindak tutur menyatakan dilakukan oleh pesulap untuk mengungkapkan perasaan bangga kepada presenter sekaligus orang 
yang telah berjasa terhadap prestasi yang sudah dicapai pesulap. Realisasi tindak tutur menyatakan yang dilakukan pesulap berupa mengungkapkan perasaan suka cita berupa tuturan terima kasih dengan cara menyatakan kalimat yang membanggakan presenter. Hal ini dapat dilihat pada kutipan kalimat berikut.

Pesulap : Mungkin banyak orang yang belum tau sampai detik ini seperti apa dan ini belum pernah gue katakan sebelumnya. Eee akhirnya gue bisa sampai ke America's Got Talent. Gue dulu empat tahun pernah belajar sama Deddy Corbuzier, jadi gue mau bilang terima kasih udah ngajarin gue.

Presenter : I'm so Proud. (Youtube Hitam Putih Trans7 Official. Kisah Demian Aditya Perform di Amerika. Edisi 4-2, 09 Juni 2017)

Konteks percakapan tersebut adalah ungkapan suka cita pesulap dengan cara mengungkapkan terima kasih kepada presenter yang sudah mengajar selama empat tahun. Ungkapan tentang topik menyatakan oleh pesulap tersebut disampaikan dalam bentuk kalimat asertif menyatakan "gue dulu empat tahun pernah belajar sama Deddy Corbuzier, jadi gue mau bilang terima kasih udah ngajari gue" Tuturan asertif menyatakan bermaksud untuk mengungkapkan informasi tentang Deddy Corbuzier yang sudah melatih pesulap disertai ungakapan perasaan suka cita pesulap kepada presenter dengan memakai penanda "terima kasih". Di samping itu, tuturan menyatakan ditandai dengan pemakaian penanda lingual "jadi" yang diperkuat dengan ekstralingual "gue mau bilang terima kasih udah ngajarin gue"
Tuturan asertif disampaikan pesulap menggunakan strategi langsung literal dengan konteks aksional. Strategi tuturan langsung literal diindikasi dari perasaan yang sama dengan kata-kata penyusunnya yaitu kalimat menyatakan. Konteks aksional pesulap ditandai dengan gerakan tangan berupa permintaan jabat tangan mengarah pada presenter untuk melengkapi pesan verbal dalam tuturan menyatakan. Melalui konteks aksional ini, dapat memberikan tanggapan verbal oleh presenter berupa membalas permintaan jabat tangan pesulap tersebut. Tuturan asertif menyatakan antara kelas menengah pesulap dan presenter terdapat penggunaan kalimat variasi akrolek dengan penanda gue yang arti sebenarnya adalah "saya" sapaan untuk menyebutkan kata ganti orang pertama tunggal. Penanda Gue dalam kalimat menunjukkan pesulap menggunakan bahasa Indonesia dialek Jakarta.

Tindak tutur menyatakan dilakukan pengamat pendidikan untuk menyatakan suatu informasi berdasar fakta yang disertai dengan kata permohonan maaf. Kalimat menyatakan yang dilakukan oleh pengamat pendidikan berupa tuturan asertif. Hal ini dapat dilihat pada kutipan data berikut.

$\begin{array}{llr}\text { Pengamat Pendidikan } & \text { Maaf ni bro, } \\ & \begin{array}{l}\text { kebanyakan } \\ \text { kayaknya }\end{array} & \text { orang } \\ \text { tua tidak } & \text { mampu } \\ & \text { jadi piti } & \text { karena } \\ \text { tidak } & \text { terbiasa } \\ \text { untuk itu } & \\ \text { Presenter } & \text { Iya, } & \text { bener. } \\ & \text { (Youtube } & \text { Hitam } \\ & \text { Putih } & \text { Trans7 } \\ & \text { Official. } & \text { Tri } \\ & \text { Adinata, Guru Viral } \\ & \text { Mengajar r } & \text { Gitar } \\ & \text { dengan } & \text { Energik. }\end{array}$


Edisi 1, 25 Maret 2020)

Tindak tutur menyatakan dalam percakan dialog diawali dengan menyatakan ungkapan perasaan dengan penanda kesantunan "maaf" yang mengandung fungsi untuk mengemukakan apa yang dipikirkan Pengamat Pendidikan dalam bentuk kalimat "kebanyakan kayaknya orang tua tidak mampu jadi guru karena tidak terbiasa untuk itu". Kata maaf berguna untuk menghindari permasalahan mengenai percakapan yang disampaikan pengamat pendidikan. Tuturan asertif menyatakan pengamat pendidikan bertujuan untuk menyampaikan suatu informasi yang diketahui pengamat pendidikan berdasar fakta yang kemudian disampaikan kepada presenter melalui katakata.

Makna asertif ini, semakin dirasakan Presenter dengan strategi langsung literal yang diungkapkan pengamat pendidikan. Strategi tuturan langsung literal diindikasikan dari perasaan atau informasi yang sama dengan kata-kata penyusunnya. Penggunaan tuturan asertif menyatakan mengandung konteks aksional dari pengamat pendidikan yang ditandai melalui pesan verbal berupa gerakan tangan, sikap mata, dan wajah menghadap Presenter. Tuturan asertif menyatakan golongan kelas menengah antara pengamat pendidikan dan presenter, diawali dengan pengungkapan "maaf bro" ungkapan bro merupakan penanda penggunaan bahasa Indonesia dialek Jakarta, yakni akrolek. Kata bro digunakan sebagai kata ganti orang yang biasa digunakan oleh laki-laki.

Sehubungan dengan kegiatan komunikasi. Presenter mengungkapan kalimat menyatakan terpusat pada informasi yang telah diterima sebelumnya untuk kemudian dinyatakan kembali pada mitra tutur. Hal tersebut dilakukan presenter untuk memberikan penekanan suatu informasi yang didapatnya. Selain itu,

presenter berupaya untuk mendapat informasi lebih lengkap seperti pada kutipan berikut.

Presenter

Seniman

Pengusaha

\section{: Jadi, lebih banyak temen aktrisnya ya. \\ Rafi Ahmad, Ayu Ting \\ Ting, Jessica Iskandar, Mas Dias itu lagi. Itu gimana ceritanya sampai bisa kenal sama mereka.}

: Eee tapi, kalo kenal Rafi Ahmad, Ayu Ting Ting, sama Jeddar kayanya ngga perlu susah-susah, karena satu tempat kan kumpul semua mereka itu.

: Ya, jadi kenal karena
Jalan. (Youtube Hitam
Putih Trans7 Official.
Rudy Salim, Pebisnis
Muda Berpenghasilan
Miliaran Rupiah. Edisi 2,
06 November 2018)

Tuturan asertif menyatakan diungkapkan presenter untuk meyakini suatu kebenaran yang diketahui presenter. Tuturan menyatakan yang diujarkan presenter ditandai dengan kata lingual "jadi" dilengkapi ekstralingual dengan penanda kalimat "lebih banyak temen artisnya ya". Penggunaan kata "ya" diberi penekanan khusus dalam tuturan, hal tersebut sebagai bentuk kebenaran informasi yang diterima presenter. Maksud ungkapan menyatakan, menunjukkan bahwa kalimat tersebut mengandung makna 
asertif yaitu mengungkapkan pikiran presenter berdasar fakta tentang lingkungan sosial pengusaha yang disampaikan di tengah-tengah kegiatan komunikasi berlangsung, sehingga presenter memilih dengan menggunakan strategi tuturan langsung literal agar pesan yang diujarkan diterima oleh pengusaha. Penyampaian ungkapan menggunakan pemakaian bahasa akrolek dialek Jakarta dalam kalimat "jadi, lebih banyak temen aktrisnya ya" ditandai dengan penggunakan kata temen yang dituturkan presenter yang memiliki arti sebenarnya yaitu "teman".

\section{Tindak Tutur Asertif Membual}

Dalam kegiatan interaksi komunikasi, pesulap berupaya untuk membuat komunikasi berjalan sebaik mungkin dengan cara menuturkan kalimat bualan agar komunikasi yang berlangsung tidak terlalu formal sehingga hal tersebut akan memberikan efek positif terhadap kegiatan berkomunikasi.

$\begin{array}{ll}\text { Pesulap } & \text { : Ya Pak, lumayan itu Pak. } \\ & \text { Satu mobil dapet itu } \\ & \text { Pak. } \\ \text { Presenter } & \text { : Pasirnya ngga dong? } \\ & \text { (Youtube Hitam Putih } \\ & \text { Trans7 Official. Kisah } \\ & \text { Demian Aditya Perform di } \\ & \text { Amerika. Edisi 4-2, 09 } \\ & \text { Juni 2017) }\end{array}$

Tindak tutur asertif membual dalam percakapan merupakan kegiatan percakapan pesulap dengan presenter dalam interaksi berapa harga barang yang di kirim ke Amerika. Konteks percakapan tersebut adalah pesulap membual ketika ditanya mengenai harga pengiriman, ditandai dengan kalimat "satu mobil dapet itu Pak" Tuturan asertif membual bertujuan untuk memberitahukan suatu informasi tentang harga yang direalisasikan dalam bentuk kalimat bualan "satu mobil dapet itu Pak" tidak menyebut nominal harga pengiriman.

Tuturan asertif disampaikan pesulap menggunakan strategi tidak langsung dengan konteks aksional. Strategi tuturan tidak langsung diindikasikan dari maksud memberikan suatu informasi kepada presenter tetapi tuturan pesulap diungkapkan dengan membual atau maksud diungkapkan berbeda dari kata-kata penyampaiannya. Konteks aksional dalam mengungkapkan bualan tersebut memberikan pesan verbal dengan menggerakkan tangan di lutut, sikap wajah dan mata menghadap ke arah presenter. Percakapan kelas sosial pesulap dan presenter menggunakan salah satu bentuk variasi bahasa. Tuturan bualan pesulap tentang harga pengiriman barang disampaikan dalam bentuk variasi bahasa akrolek, dengan memakai penanda bahasa Indonesia dialek Jakarta dapet tuturan akrolek tersebut bermakna "dapat" dalam arti sebenarnya.

Tuturan asertif membual juga dilakukan presenter untuk mengungkapkan ketidaktahuan mengenai informasi yang baru diketahui presenter. Presenter dalam melakukan tuturan asertif membual yaitu dengan cara memberikan intonasi penekanan berupa ekspresi tertawa dalam membual.

Presenter : Gue pikir cuma ada di mobil mainan yang kayak gini, ternyata realnya ada ya.

Pengusaha : CCR itu dibikin sekitar tahun sembilan empat, sebenarnya membuat mobil ini form industry dan masih hidup orangnya, special 
coenigsegg namanya.

(Youtube Hitam Putih

Trans7 Official. Rudy

Salim, Pebisnis Muda

Berpenghasilan Miliaran

Rupiah. Edisi 2, 06

November 2018)

Kegiatan melakukan tuturan asertif membual merupakan selingan dalam melalukan kegiatan berkomunikasi atau percakapan. Realisasi tuturan membual yang dilakukan presenter berupa ungkapan tentang pengetahuan yang baru didapat tentang mobil mewah. Tuturan membual presenter terdapat pada kalimat " gue pikir cuma ada di mobil mainan yang kayak gini ternyata realnya ada ya". Tuturan asertif presenter bertujuan untuk mengungkapkan pikiran berupa informasi tentang mobil mewah yang ada dalam bentuk nyata, ungkapan tersebut diujarkan presenter dengan membual namun menggunakan intonasi berita.

Tuturan asertif membual tersebut disampaikan presenter dengan menggunakan strategi tuturan langsung literal, agar maknanya dapat diterima oleh pengusaha. Di samping itu, tuturan asertif membual presenter disertakan dengan konteks aksional, hal ini bertujuan untuk memberikan pesan verbal dengan sikap wajah dan pandangan mata pada pengusaha. Dalam percakapan kelas sosial menengah presenter dengan pengusaha, kata ganti seseorang tunggal diwujudkan dengan tuturan akrolek dengan memakai penanda gue, yang mana kata tersebut merupakan kata tuturan yang memiliki arti sebenarnya yaitu "saya".

Kegiatan komunikasi dengan tuturan kalimat membual dilakukan dengan cara mengungkapkan kalimat omong kosong dengan menggunakan tuturan asertif sesuai kebenaran yang ada. Hal ini dimaksudkan untuk menuntun komunikasi mengarah pada komunikasi santai atau non formal.
Dari sini akhirnya bisa dihasilkan komunikasi yang lebih berkembang.

$\begin{array}{ll}\text { Presenter } & \text { : Apa, apa kunci sukses lo. } \\ & \text { Menurut lo sendiri. } \\ \text { Pengusaha } & \text { : Ya sebenarnya, saya } \\ & \text { dulunya mau jadi } \\ & \text { pesulap yang bisa } \\ & \text { bengkokin sendok, tapi } \\ & \text { otak saya yang bengkok. } \\ & \text { (Youtube Hitam Putih } \\ & \text { Trans7 Official. Rudy } \\ & \text { Salim, Pebisnis Muda } \\ & \text { Berpenghasilan Miliaran } \\ & \text { Rupiah. Edisi 2, 06 } \\ & \text { November 2018) }\end{array}$

Konteks percapakan tersebut adalah tuturan membual pengusaha ketika ditanya kunci sukses oleh presenter. Pengusaha menyampaikan tuturan asertif membual ditengah-tengah kegiatan percakapan berlangsung. Tuturan membual pengusaha berupa kalimat tuturan "saya dulunya mau jadi pesulap yang bisa bengkokin sendok, tapi otak saya yang bengkok". Dalam kalimat bualan tersebut, pengusaha menggunakan kata konjungsi "tapi” sebagai penyambung dengan kalimat sebelumnya.

Tuturan asertif membual tersebut diungkapkan pengusaha dengan strategi tidak literal dengan konteks aksional. Tuturan tidak langsung diindikasikan dari maksud memberikan suatu informasi kepada presenter tetapi tuturan diungkapkan dengan kata-kata berbeda dalam penyusunnya atau dengan cara membual. Realisasi konteks aksional dalam tuturan pengusaha ini, dengan menggunakan pandangan mata, sikap wajah, dan senyum. Melalui pesan verbal pengusaha tersebut dapat memberikan respon ekspresi tertawa presenter. Tuturan asertif golongan kelas 
menengah pengusaha pada presenter disampaikan presenter dengan imbuhan penggunaan bahasa Indonesia dialek Jakarta atau disebut dengan variasi akrolek yang diwujudkan dalam kata bengkok, kata tersebut memiliki arti sebenarnya yaitu "berkelok".

\section{Tindak Tutur Asertif Menyarankan}

Melalui tuturan asertif menyarankan staf khusus, dalam upaya meningkatkan keteraturan dan membentuk etika masyarakat dalam kehidupan, staf khusus memberikan saran berdasar fakta yang ada kepada masyarakat. Hal ini memungkinkan membangun sikap masyarakat agar lebih berhati-hati.

\section{Staf Khusus : Makanya harus hati-hati banget, makanya penting punya critical thingking, karena jika kita ngga bisa berfikir, maka kita akan gampang \\ kena hoax. Kita ngga akan bisa menfilter mana yang bener mana yang ngga gitu.}

Presenter : Apalagi menyebar hoax sekarang gampang banget. (Youtube Hitam Putih Trans7 Official Billy, Anak Penjual Kue Asal Papua yang Jadi Staf Khusus Presiden. Edisi 1, 26 November 2019)

Tindak tutur asertif menyarakan dalam percakapan staf khusus dan presenter merupakan suatu aktivitas tuturan staf khusus dengan presenter dalam interaksi tentang crical thinking. Dalam konteks tuturan tersebut, staf khusus menyarankan untuk hati-hati menerima suatu informasi serta dapat membedakan mana yang benar dan tidak benar. Pernyataan tentang asertif menyarankan oleh staf khusus tersebut disampaikan dengan tuturan "makanya harus hati-hati banget, makanya penting punya critical thingking, karena jika kita ngga bisa berfikir, maka kita akan gampang kena hoax". Tuturan tersebut mengandung makna asertif menyarankan yang bertujuan untuk memberitahukan informasi berdasar keadaan sebenarnya atau fakta sebenarnya yang diketahui oleh staf khusus untuk disampaikan kepada presenter. Tuturan asertif menyarankan suatu informasi tersebut menggunakan kalimat berdiatesis aktif. Dikatakan demikian, karena tuturan tersebut menggunakan subjek gramatikal, yaitu "kita".

Tuturan asertif menyarankan disampaikan staf khusus dengan menggunakan strategi langsung dengan konteks aksional. Strategi tuturan langsung diindikasikan dari tuturan dengan modus kalimat sesuai dengan maksud tuturan dan kata-kata penyampaiannya. Konteks aksional dalam mengungkapkan bualan tersebut memberikan pesan verbal dengan menggerakkan tangan sikap wajah dan mata menghadap presenter. Tuturan menyarankan oleh staf khusus tentang pentingnya crical thinking disampaikan dalam bentuk variasi bahasa akrolek, dengan memakai penanda bahasa Indonesia dialek Jakarta dapet "dapat", ngga "tidak", dan bener yang berarti "benar". Tidak hanya itu, sisipan penggunaan bahasa Inggris digunakan oleh staf khusus dalam tuturan mamakai penanda critical thingking yang artinya berfikir kritis. Kata hoax dalam artian sebenarnya adalah berita bohong, Penggunaan bahasa Inggris oleh staf khusus sebagai wujud penggunaan variasi bahasa bergengsi dalam bentuk bahasa Inggris yang digunakan oleh kalangan kelas menengah.

Di samping itu, tuturan asertif menyarankan juga digunakan presenter untuk membangkitkan semangat dan 
kepercayaan diri aktris dalam nilai positif profesi seorang jurnalis. Hal ini dimaksudkan presenter untuk memberikan suatu informasi yang tidak banyak diketahui oleh masyarakat tentang keuntungan menjadi profesi jurnalis.

$\begin{array}{ll}\text { Aktris } & \text { : Mbak Nana ini kan pinter } \\ & \text { banget ya, kan cocok gitu } \\ & \text { kayaknya kalo misalkan } \\ & \text { jadi Gubernur, gitu-gitu. } \\ & \text { Ee menteri gitu, ngga } \\ & \text { kepikiran gitu? } \\ \text { Presenter } & \text { :Jangan-jangan, mending } \\ & \text { jurnalis udah bener. ini } \\ & \text { salah ngomong paling } \\ & \text { surat KPI. Gubernur salah } \\ & \text { ngomong penjara itu mah. } \\ & \text { Saya mikirnya gitu, kita } \\ & \text { bisa mempengaruhi orang. } \\ & \text { (Youtube Hitam Putih } \\ & \text { Trans7 Official. Najwa } \\ & \text { Shihab: Tamu Istimewa. } \\ \text { Edisi 3-4, 09 Januari 2018) }\end{array}$

Tindak tutur asertif menyarankan dilakukan oleh seniman dalam konteks mengungkapkan anggapan kepada aktris berupa kata-kata yang meyakinkan. Seniman dalam merealisasikan tuturan menyarankan, mengarah pada tidak setujunya terhadap pernyataan yang diungkapkan oleh aktris dengan memakai penanda kalimat "mending begini udah bener. Ini salah ngomong paling surat KPI". Seniman menggunakan konjungsi perbandingan dengan memakai penanda "mending" yang berwujud kata transisi antar kalimat yang difungsikan untuk menguraikan perbedaan jurnalis dengan gubernur atau wakil rakyat. Pronomina penunjuk umum "ini" dalam kalimat mengacu pada kata "jurnalis" yang telah disebut sebelumnya. Seniman juga menggunakan singkatan dalam tuturan berupa penanda "KPI" yang berarti key performance indicators.

Agar tuturan asertif menyarankan mudah diterima dan dipahami oleh aktris, seniman menyampaikan tuturan menggunakan strategi langsung literal, karena strategi tuturan langsung diindikasikan dari tuturan dengan modus kalimat sesuai dengan maksud tuturan. Konteks aksional seniman berupa gerakan tangan naik turun di depan dada, hal ini bertujuan untuk memberikan pesan verbal pada aktris. Tuturan menyarankan dalam percakapan diwujudkan dalam pemakaian variasi bahasa akrolek kelas menengah seniman dan presenter dengan memakai kalimat "mending begini udah bener" yang mana arti sebenarnya dalam kalimat tersebut yaitu "lebih baik seperti ini sudah benar".

Hal penting yang dilakukan majikan sehubungan dengan kegiatan komunikasi adalah memberikan saran terhadap asisten rumah tangga. Dalam hal ini tuturan asertif menyarankan digunakan majikan untuk memberikan saran pada asinten rumah tangga agar menerapkan dalam kehidupan sehari-hari.

$\begin{array}{ll}\text { Majikan } & \begin{array}{l}\text { : Susi Hayati asam urat, tapi } \\ \text { sukanya ngemil gorengan. } \\ \text { Tidur yang cukup, ngga } \\ \\ \end{array} \\ & \text { usah nungguin kita } \\ \text { pulang kerja. } & \\ \text { Presenter } & \text { : Oo masih suka nungguin? } \\ \text { Majikan } & \text { : Iya } \\ \text { Asisten } & \text { : Yaa saya nungguin sambil } \\ & \text { nonton TV. (Youtube } \\ & \text { Hitam Putih Trans7 } \\ & \text { Official. Viral, Anak } \\ & \text { Majikan Memberangkatkan } \\ & \text { Umroh Pengasuhnya. Edisi } \\ & \text { 3, 04 Desember 2018) }\end{array}$


Konteks tuturan asertif menyarankan dalam percakapan adalah ungkapan saran dari majikan kepada asisten agar tidur yang cukup dan tidak perlu menunggu majikan pulang kerja. Tuturan asertif menyarankan majikan kepada asisten adalah ungkapan perasaan dari majikan berdasar fakta yang diamati dari asisten "tidur yang cukup, ngga usah nungguin kita pulang kerja". Majikan menggunakan penanda tuturan "ngga usah" sebagai saran agar asisten tidak menunggu majikan pulang.

Agar tuturan menyarankan tersebut dapat diterima oleh asisten, majikan menggunakan tuturan langsung literal, karena perasaan yang sama dengan katakata penyusunnya yaitu kalimat menyarankan. Konteks aksional majikan diwujudkan dalam bentuk gerakan tangan memegang lutut asisten, sikap wajah, dan pandangan mata yang mengarah pada asisten. Terdapat tuturan akrolek bahasa Indonesia dialek Jakarta yang digunakan oleh majikan berupa kata ngga yang berarti "tidak". Kata tidak adalah suatu wujud penolakan.

\section{Tindak Tutur Asertif Mengeluh}

Pada kegiatan berkomunikasi, antarpenutur diharapkan dapat meluapkan perasaan duka yang kemudian diujarkan dalam bentuk tuturan yang dalam hal ini adalah tuturan asertif mengeluh. Tujuannya adalah untuk menyampaikan kesedian berdasar fakta yang diamati dengan membangun suasana tidak bahagia dalam kegiatan berkomunikasi.

Presenter : yang bikin gue sedih adalah komen-komen orang Indonesia. Itu ngga punya otak. Kebanyakan.. ndak semua orang Indonesia ya, kebanyakan yang ada komen bukan

kebanyakan dari kalian.

$\begin{array}{ll}\text { Pesulap } & \text { : Apa? } \\ \text { Presenter } & \text { : Bagus } \\ \text { Presenter } & \text { : Akhirnya gue bikin } \\ & \text { youtube ya, karena gue } \\ & \text { kesel banget pada saat itu. } \\ & \text { Jadi itu, alay semua yang } \\ & \text { komen, kok ngga mikir } \\ & \text { gitu lo maksudnya. } \\ & \text { (Youtube Hitam Putih } \\ & \text { Trans7 Official. Kisah } \\ & \text { Demian Aditya Perform di } \\ & \text { Amerika. Edisi 4-2, 09 } \\ & \text { Juni 2017) }\end{array}$

Tindak tutur ekspresif mengeluh dalam dialog merupakan percakapan yang terjadi antara presenter dan pesulap. Konteks percakapan tersebut adalah presenter mengeluhkan cara orang-orang Indonesia memberikan komentar pada orang lain, hal ini diujarkan presenter dalam kalimat "yang bikin gue sedih adalah komen-komen orang Indonesia". Tuturan Asertif mengeluh bertujuan untuk mengungkapkan perasaan sedih pesulap kepada presenter dengan memakai penanda "gue sedih". Terdapat pemakaian pengulangan atau reduplikasi seluruhnya pada penanda "komen-komen" tanpa merubah kelas kata.

Tindak tutur asertif mengeluh yang terdapat dalam percakapan pesulap termasuk tuturan langsung karena memiliki modus dan fungsi tuturan yang sesuai. Di samping itu, konteks aksional pesulap ditandai dengan gerakan tangan diletakkan di depan dada. Melalui konteks aksional ini, dapat memberikan pesan verbal presenter dalam menyampaikan tuturan mengeluh. Tuturan asertif menyatakan "yang bikin gue sedih adalah komen-komen orang Indonesia". Kalimat tersebut merupakan kalimat dengan penggunaan variasi akrolek 
dengan penanda gue yang arti sebenarnya adalah "saya" sapaan untuk menyebutkan kata ganti orang pertama tunggal. komen dalam arti sebenarnya adalah "komentar" dalam tuturan. Ungkapan percakapan kelas menengah presenter dan pesulap dalam pemakaian akrolek tersebut, variasi akrolek merupakan variasi bahasa yang digunakan untuk terciptanya suasana akrab dan menunjukkan kelas sosial keduanya.

Pada tindak tutur asertif mengeluh ini, jurnalis berkesempatan menyampaikan keluhan berupa tuturan dengan menyampaikan ungkapan duka yang membuatnya merasa sedih dalam kegiatan berkomunikasi. Kegiatan mengkomunikasikan kesedihan ini berdasar dengan apa yang dirasa atau dialami jurnalis.

Pengacara

$$
\begin{aligned}
& \text { : Untungnya kita punya } \\
& \text { supir cukup, jadi saya } \\
& \text { ngga harus selalu jadi } \\
& \text { supirnya. }
\end{aligned}
$$

Jurnalis $\quad$ : Itu selalu jadi resiko yang jadi keinget waktu nonton youtube dirimu yang bilang resolusi. Setiap tahun resolusiku selalu belajar nyupir, tapi setiap tahun ndak pernah siap.

\section{Lo pas ngomong resolusi} selalu gagal langsung jlep. Wah ini gua banget nih, ya bener ngga bisa nyupir mobil. (Yotube

Hitam Putih Trans7 Official. Najwa Shihab: Tamu Istimewa. Edisi 34, 09 Januari 2018)

Konteks Tindak tutur asertif mengeluh dilakukan oleh jurnalis untuk menyatakan kesedihan atau kekecewaan terhadap resolusi setiap tahun yang tidak pernah terlaksana. Kalimat mengeluh percakapan jurnalis dan pengacara berupa kalimat "lo pas ngomong langsung jlep. wah ini gua banget nih, ya bener ngga bisa nyupir" dengan memberikan penekanan tuturan mengeluh khusus pada bagian kata "jlep" dan "ngga bisa". Tuturan asertif mengeluh jurnalis bertujuan untuk mengungkapan perasaan kecewa dengan penanda "njep". Terdapat penambahan partikel wah dalam kalimat. Pronomina penunjuk umum "ini" dalam kalimat mengacu pada "resolusi" yang telah disebut sebelumnya. Penambahan partikel nih sebagai kata empatik dengan penekanan khusus.

Tuturan asertif mengeluh disampaikan jurnalis dengan strategi langsung literal karena memiliki modus dan fungsi tuturan yang sesuai. Kalimat asertif mengeluh yang dimaksudkan golongan kelas menengah jurnalis pada pengacara berupa ungkapan kesedihan yang mengandung pemakaian variasi bahasa akrolek. Ungkapan jurnalis dalam pemakaian akrolek tersebut diwujudkan dengan penanda lo, pas, jlep, gue, banget, bener, dan ngga pada tuturan, yang merupakan ciri dari bahasa Indonesia berdialek Jakarta. Penggunaan kata lo sebagai kata ganti penunjuk orang yaitu "kamu". Partikel pas dalam tuturan memiliki arti "waktu", gue memiliki arti sebenarnya adalah "saya" sapaan untuk menyebutkan kata ganti orang pertama tunggal. Kata banget memiliki arti "sangat", dan bener "benar". Melalui ungkapan pemakaian akrolek tersebut, variasi akrolek merupakan variasi bahasa yang digunakan untuk terciptanya suasana akrab dan menunjukkan kelas sosial keduanya.

Tidak hanya perasaan sedih terhadap diri sendiri, ungkapan perasaan sedih bisa bersifat meluas berdasar realita atau keadaan eksternal dan kilas balik pada masa lalu dapat memunculkan perasaan sedih presenter dengan menggunakan metode perbandingan terhadap perbedaan zaman. 
Presenter : Wah, anda ini guru musik kan. Saya sedih, zaman saya kok ngga begini ya? zaman saya guru musik saya, nyanyi sumbang lempar pake penghapus.

Guru : Ee sebenernya guru jaman sekarang itu harus, ini ya. Harus menyentuh hati anak-anak terlebih dahulu, jadi kita harus pahamkan bahwa kita juga sayang sama mereka, sama seperi keluarga mereka sayang sama mereka.

(Youtube Hitam Putih Trans7 Official. Tri Adinata, Guru Viral Mengajar Gitar dengan Energik. Edisi 1, 20 maret 2020)

Konteks tuturan mengeluh dalam percakapan dilakukan presenter setelah menyaksikan pertunjukan guru sebelum kegiatan komunikasi, untuk menyatakan perasaan kecewa karena presenter tidak merasakan hal yang sama seperti peserta didik yang diajar oleh guru. Tuturan kalimat mengeluh presenter "saya sedih. Zaman saya kok ngga begini ya". Tuturan asertif mengeluh presenter bertujuan untuk menyampaikan perasaan sedih yang dirasakan presenter. Tuturan mengeluh diutarakan dalam bentuk penanda "saya sedih". Penambahan partikel kok sebagai kalimat empatik dengan memberi penekanan khusus. Pengujaran kata "ya" oleh presenter menggunakan intonai akhir rendah seperti tuturan bertanya yang membutuhkan jawaban.

Tuturan asertif mengeluh menggunakan strategi tuturan langsung, sehingga modus dan maknanya tersampaikan pada guru.
Konteks aksional presenter dilakukan dengan cara berjalan mendekati guru untuk memberi kesan verbal. Tuturan asertif menyatakan disampaikan presenter menggunakan variasi akrolek dengan menggunakan kata "ngga" dalam arti sebenarnya yaitu "tidak". Penggunaan variasi akrolek presenter menjadi salah satu wujud dari status kelas menengah presenter untuk mempertahankan status kelas menengah sosial presenter dalam hal penggunaan bahasa yang dianggap paling bergengsi.

\section{Tindak Tutur Aserif Membanggakan}

Presenter juga memberikan apresiasi bangga sebagai bentuk apresiasi terhdap prestasi, keterampilan, dan kerja keras yang sudah dicapai pengusaha. Hal ini dimaksudkan presenter untuk memberi rasa senang pada pengusaha.

$\begin{array}{ll}\text { Presenter } & \text { : Itu gimana ceritanya bisa } \\ \text { Pengusaha } & \text { : Ada beberapa usaha yang } \\ & \text { memang membutuhkan } \\ & \text { public figure jadi ya } \\ \text { akhirnya kenal. Saya ada } & \text { sempet bikin ritel area } \\ & \text { untuk FMB, makanan. } \\ & \text { Area makanan di deket } \\ & \text { Bandara Soekarno Hatta, di } \\ & \text { sebalah kiri. Area makan } \\ & \text { delapan ribu meter itu saya } \\ & \text { yang kelola, Nah.. artis- } \\ & \text { artis tersebut buka tempat } \\ & \text { makan disitu, jadi yaa } \\ & \text { akhirnya kenal, seperti itu. } \\ & \text { : Wah.. hebat banget ya, } \\ & \text { berani gitu untuk ngambil } \\ & \text { usaha segala macem. } \\ & \text { (Youtube Hitam Putih } \\ \text { Trans7 Official. Rudy } & \text { Salim, Pebisnis Muda } \\ \text { Presenter } & \text { Berpenghasilan Miliaran } \\ & \text { Rupiah. Edisi 2, 09 Juni } \\ \text { 2017) }\end{array}$


Tuturan asertif membanggakan dilakukan presenter untuk menunjukkan rasa kagum pada pengusaha yang memiliki berbagai macam usaha. Realisasi tindak tutur membanggakan yang dilakukan presenter menggunakan penanda kata "wah, hebat banget ya" melalui ungkapan penanda tersebut dapat memperjelas makna perasaan presenter. Dalam kalimat tersebut diberikan penekanan khusus pada partikel wah. Hal ini dimaksudkan Presenter sebagai ungkapan kekaguman. Tuturan ilokusi yang bermakna asertif membanggakan tersebut disampaikan Presenter secara langsung, agar modus dan maknanya dapat diterima dengan mudah oleh pengusaha. Penggunaan tuturan asertif menyatakan mengandung konteks aksional presenter yang ditandai dengan pesan verbal berupa sikap mata dan wajah menghadap pengusaha. Melalui konteks aksional ini, presenter mendapat respon balik berupa pesan verbal pandangan mata, sikap wajah, dan senyum dari pengusaha.

Dalam tuturan asertif membanggakan yang dilakukan presenter, presenter memakai variasi akrolek pada penggunaan kata banget dan macem. Ungkapan bangga berupa kata banget bukanlah kata sebenarnya, kata banget dalam arti sebenarnya adalah sekali dan sangat. Kata macem yang berarti "macam". Saat ini pemakaian akrolek telah digunakan oleh beberapa public figure di acara televisi karena dianggap sebagai variasi bahasa yang paling bergengsi terlebih dikalangan komunitas kelas menengah seperti Presenter dan Pengusaha tersebut.

Di akhir kegiatan berkomuniaksi, presenter memberikan klarifikasi mengenai kualitas pekerjaan pengusaha berdasar pengalaman yang sudah diceritakan oleh pengusaha. Dengan maksud itulah presenter mengunakan tuturan membanggakan dalam bentuk tuturan asertif.
Presenter

\section{: Thank you banget, luas \\ biasa. Kita belajar \\ positifnya dari sini ya, \\ bahwa ternyata ilmu itu \\ bisa dipelajari juga di luar \\ sekolah dan saya punya. \\ Gue pernah denger gini \\ 'kalo lo kerja keras untuk \\ sesuatu yang lo ndak suka \\ itu namanya stress' tapi, \\ kalo lo bekerja untuk \\ sesuatu yang lo suka itu \\ namanya passion.

\begin{tabular}{|c|c|c|}
\hline Hitam & Putih & Trans 7 \\
\hline Official. & Rudy & Salim \\
\hline Berpengh & asilan & Miliarar \\
\hline $\begin{array}{l}\text { Rupiah. } \\
\text { 2017) }\end{array}$ & Edisi 2, & 09 Jun \\
\hline
\end{tabular}

Pengusaha : Betul, betul. (Youtube

Tindak tutur asertif membanggakan terjadi dalam percakapan antara presenter dengan pengusaha. Konteks dalam percakapan tersebut adalah presenter memuji pengusaha yang belajar tidak hanya dari sekolah melainkan luar sekolah. Presenter membanggakan pengusaha dengan penanda tuturan "thank you banget, luas biasa". Apresiasi ungkapan perasaan bangga ditandai dengan ungkapan "luar biasa" yaitu suatu pernyataan yang bernosi membanggakan terhadap prestasi pengusaha.

Tuturan asertif membanggakan ini semakin dirasakan oleh pengusaha dengan starategi langsung yang dibawakan presenter agar maksud dan tujuannya dapat diterima dengan jelas. Tidak sedikit, konteks aksional dilakukan dalam kegiatan berkomunikasi. Hal ini, bertujuan untuk memberi pesan verbal dalam tuturan. Konteks aksional verbal dalam tuturan asertif membanggakan presenter berupa sikap wajah, mata, dan senyuman agar makna perasaan bangga presenter kepada pengusaha tidak hanya melalui tuturan, 
melainkan juga melalui apresiasi penggunaan pesan verbal presenter. Dalam tindak tutur asertif membanggakan ini mengandung sisipan pemakaian akrolek yang dianggap variasi bahasa paling bergengsi diantara varietas bahasa yang lain, pemakaian akrolek dibuktikan dengan penanda kata banget yang mana artinya yaitu "terima kasih sekali". Tidak hanya menggunakan dialek Jakarta, presenter juga menggunakan bahasa Inggris untuk menambah kesan bahasa bergengi berupa kata thank you, yang memiliki arti terima kasih.

Tuturan membanggakan yang diutarakan asisten rumah tangga agar komunikasi berlangsung dengan baik. Hal ini dimaksudkan agar kegiatan mengkomunikasikan ini berimbas pada perolehan saling menyampaikan sikap positif yang sudah memberikan rasa bangga untuk asisten rumah tangga. Oleh karena itu, dalam menyampaikan tuturan bangga. Asisten rumah tangga menggunakan tuturan asertif agar penyampaiannya bisa logis.

\section{Majikan : Udah kayak nenek sendiri, udah bagian dari keluarga kita \\ Asisten : Saya seneng kan. Anakku}

hebat rek. (Youtube Hitam Putih Trans7 Official.

Viral, Anak Majikan

Memberangkatkan Umroh

Pengasuhnya. Edisi 3, 04

Desember 2018)

Tindak tutur asertif membanggakan terjadi dalam percakapan majikan dan asisten rumah tangga. Konteks percakapan tersebut adalah ungkapan membanggakan asinsten rumah tangga kepada majikan yang sudah dianggap seperti keluarga. Ungkapan membanggakan asisten disampaikan dengan penanda "Anakku hebat rek". Tuturan asertif membanggakan asisten bermaksud untuk mengungkapkan perasaan senang atau bangga pada majikan dengan memakai penanda "hebat". Dalam tuturan terdapat imbuhan kata rek dengan memberikan penekanan khusus, rek dalam tuturan sebagai penunjuk orang, penunjuk orang yang dimaksud asisten adalah adalah majikan.

Tuturan asertif disampaikan asisten menggunakan strategi langusung dengan menggunakan konteks aksional. strategi tuturan langsung literal diindikasi dari perasaan yang sama dengan kalimat penyusun dalam menyatakan membanggakan. Di samping itu, konteks aksional ditandai dengan pandangan mata dan senyum dari asisten untuk menyampaikan pesan verbal dalam tuturan membanggakan. Melalui konteks aksional ini, dapat memberikan tanggapan verbal majikan berupa sentuhan tangan dilutut asisten rumah tangga. Dalam tuturan asertif membanggakan asisten, asisten menggunakan akrolek bahasa Indonesia dialek Jakarta yaitu hebat yang artinya terlampau atau luar biasa. Tidak hanya itu, asisten juga menambahkan kata lingual dialeg bahasa Jawa orang Surabaya yaitu rek. Rek dalam bahasa Indonesia adalah tiruan bunyi pisau, namun dalam bahasa Jawa kata rek adalah arti lain dari kata arek sebagai kelas nomina atau penunjuk seseorang.

\section{PEMBAHASAN}

Perbedaan jenis kelamin, usia, hubungan antar-penutur, komunitas kelas sosial, tujuan bertutur, dan tempat komunikasi itu terjadi, dipercaya sebagai faktor keberagaman varietas bahasa yang digunakan oleh anggota dalam suatu komunitas. Hal ini dapat diamati melalui komunikasi antar-penutur, situasi dalam komunikasi, isi tuturan, dan fungsi tuturan yang memungkinkan adanya perbedaan proses komunikai dengan penggunaan variasi bahasa dan cara bicara yang tidak sama satu sama lain. 
Penggunaan varietas bahasa tertentu dalam suatu komunitas dipercaya sebagai upaya menjembatani terjalinnya komunikasi dengan baik, terjalin keakraban, dan dapat dimengerti antar-penutur. Variasi bahasa dalam kehidupan masyarakat terdiri dari berbagai macam bentuk meliputi: akrolek, basilek, vulgar, slang, kolokial, jargon, argot, ken, variasi bahasa dari segi pengguna bahasa, serta variasi bahasa dari segi keformalan Chaer dan Leonie Agustina (dalam Jaelani, 2015:2).

Pemakaian varietas bahasa berupa akrolek merupakan varietas bahasa yang memiliki tingkat kesantunan paling tinggi diantara varietas bahasa yang lain. Oleh karenanya, varietas bahasa ini, dianggap paling bergengsi. Penggunaan akrolek dalam penelitian ini digunakan antarpenutur dalam penggunaan tuturan fungsi bahasa dalam tuturan asertif.

Kegiatan gelar wicara Hitam Putih di konten youtube program acara Trans7 Official. Pemakaian variasi akrolek tampak dari penerapan fungsi tuturan asertif presenter dan narasumber. Semakin banyak informasi dan pengalaman yang diketahui penutur mengenai topik komunikasi yang berlangsung, maka semakin banyak fungsi bahasa yang digunakan dalam komunikasi. Berdasarkan hasil penelitian ini, presenter dan narasumber dalam menggunakan fungsi tuturan asertif yang mencakup: (1) tuturan asertif menyatakan terima kasih, maaf, serta tuturan menyatakan suatu informasi; tuturan asertif membual, yang banyak menggunakan tuturan tidak langsung dalam interaksi komunikasi; (3) tuturan asertif menyaran, digunakan presenter dan narasumber dalam bentuk tuturan langsung serta untuk memberikan informasi yang terdapat dalam memori penutur yang sifatnya untuk membangun sikap ke arah lebih baik; (4) tuturan asertif mengeluh, menghadirkan persepsi negatif dan ungkapan perasaan kecewa. Hal tersebut dibuktikan dengan penggunaan kata "saya sedih" dan "jlep" pada interaksi komunikasi; dan (5) tuturan asertif membanggakan, menampilkan persepsi positif dan mencari informasi yang masuk dalam memberikan apresiasi terhadap prestasi yang dicapai oleh mitra tutur. Hal ini diperkuat dengan penggunaan kata "hebat" dan "luar biasa" dalam tuturan presenter dengan narasumber.

Penggunaan fungsi tuturan asertif cederung pada pemamakaian variasi akrolek dalam tuturan. Tuturan yang demikian, bertujuan untuk mencipta suatu respon dan sebagai pemberi informasi berdasar realita atau kenyataan. Pemakaian akrolek pada tuturan asertif didasarkan pada penutur yang sebagain besar termasuk dalam komunitas kelas menengah.

Fungsi bahasa yang termasuk dalam jenis ilokusi ini menurut Searle (dalam Rachman, 2015:2-5) dapat dikategorikan ke dalam berbagai bentuk fungsi meliputi: (a) tuturan asertif menyatakan, (b) tuturan asertif mengeluh, (c) tuturan asertif menyarankan, (d) tuturan asertif mengklaim, (e) tuturan asertif membanggakan, (f) tuturan asertif melaporkan, dan (g) tuturan asertif membual.

Di antara ketujuh fungsi tindak tutur asertif tersebut, fungsi asertif yang melibatkan tuturan akrolek pada penelitian ini berupa tuturan asertif menyatakan, tuturan asertif menyarankan, tuturan asertif mengeluh, tuturan asertif membual, dan tuturan asertif membanggakan. Pada tuturan asertif yang berfungsi menyatakan ungkapan secara tidak langsung, memiliki sifat negatif yang tujuannya mengurangi ketidakharmonisan tersirat dari tujuan yang ingin dicapai penutur dan narasumber. Ungkapan secara langsung untuk menyatakan sesuatu dengan jelas, misalnya pada tuturan menyatakan, menyarankan, membanggakan, dan mengeluh.

Dalam kegiatan bertutur, strategi yang dapat diukur presenter dari komunikasi dengan narasumber adalah asertif. Oleh karena itu, 
dalam kegiatan gelar wicara banyak menerapkan tuturan langsung literal dengan menyatakan suatu informasi, memberikan saran, ungkapan membanggakan, dan mengungkapkan perasaan sedih.

\section{SIMPULAN}

Pada gelar wicara Hitam Putih di konten youtbe program acara Trans7 Official. Pemakaian akrolek presenter dan narasumber tampak pada fungsi bahasa tindak tutur asertif dalam kegiatan interaksi. Semakin banyak informasi dan perasaan yang dimiliki penutur maka semakin banyak pula perasaan atau kalimat tuturan asertif yang digunakan dalam berkomunikasi.

Berdasar penelitian ini, presenter dan narasumber menggunakan variasi bahasa akrolek pada fungsi bahasa tindak tutur asertif. Tuturan asertif ini dilakukan untuk menjalin interaksi positif antara presenter dan narasumber agar mendapat respon dengan baik. Tuturan yang banyak digunakan dalam komunikasi adalah tuturan langsung literal agar maksud dan maknanya dapat diterima dengan mudah oleh mitra tutur.

Tindakan tersebut berupa aktivitas antara presenter dengan narasumber seperti: mengungkapkan ungkapan rasa terima kasih, permohonan maaf, menyatakan, memberikan apresiasi dalam bentuk membanggakan, serta ungkapan perasaan sedih atau kecewa dengan mengeluh.

\section{DAFTAR PUSTAKA}

Arnaselis, Indri \& Rusmito N.E. 2017.Tindak Tutur Asertif dalam Roman Larasati Karya Pramoedya Ananta Toer dan Implikasinya. Jurnal Kata (Bahasa, Sastra, dan Pembelajaran). 5 (3): 1-12. Apriyanti, Linda. 2017. Tindak Tutur Asertif Penjual dan Pembeli di Pasar Tempel Rajabasa Bandar Lampung dan Ilmplikasinya pada Pembelajaran Bahasa Indonesia. Skripsi diterbitkan. Lampung: Program Studi Pendidikan
Bahasa dan Sastra Indonesia FKIP Lampung.

Apriastuti, N. N. A. A. 2017. Bentuk Fungsi dan Jenis Tindak Tutur dalam Komunikasi Siswa di Kelas IX Unggulan SMP PGRI 3 Denpasar. Jurnal Ilmiah Pendidikan dan Pembelajaran. 1 (1). 38-47.

Chaer, A. \& Leoni, A. 2014. Sosiolinguistik Perkenalan Awal. Jakarta: Rineka Cipta. Huberman, a michael, \& Milles, matthew b. (1992). Analisis Data Kualitatif. Jakarta: Universitas Indonesia.

Jaelani, A. J \& Saqina, M. 2015. Kajian Variasi Bahasa Pada Status yang Dibuat Oleh Pengguna Twitter Yang Bergabung dengan Akun Twitter Saqina Melisa Periode Januari 2014. Junal Fon, 4 (1). $1-3$.

Mujianto, Gigit. 2013. Tuturan Pejabat Negara dalam Berita "Korupsi" Pada Media Massa Cetak. Jurnal Humanity, 8 (2). $13-20$

Novitasari, D. 2015. Kesantunan Asertif dalam Bidang Tenaga Kependidikan Universitas Muhammadiyah Surakarta (UMS). Skripsi diterbitkan. Surakarta: Program Studi Pendidikan Bahasa dan Sastra Indonesia FKIP Surakarta.

Nuryani, L., Agus.B. S. \& Dhika, P. 2018. Variasi Bahasa Pada pementasan Drama CIPOA dan Sidang Para Setan Mahasiswa Pendidikan Bahasa dan Sastra Indonesia Tahun 2017. Jurnal Widyabastra. 6 (1): 62-75.

Rachman. 2015. Tindak Tutur dalam Proses Belajar-Mengajar Pada Taman KanakKanak Dharma Wanita Kelurahan Wapunto Kecamatan Duruka Kabupaten Muna (Kajian Pragmatik). Jurnal Humanika, 15 (3). 1-18.

Sari, R. R. 2016. Tindak Tutur Asertif Pada Proses Pembelajaran Bahasa Indonesia di Kelas IX SMP Negeri 17 Pesawaran Tahun Pelajaran 2016/2017 dan Implikasinya dalam Pembelajaran Bahasa Indonesia di SMP. Tesis 
diterbitkan. Bandarlampung: Magister Pendidikan Bahasa dan Sastra Indonesia FKIP Bandarlampung.

Saddhono, Kundharu. 2006. Bahasa Etnik Madura di Lingkungan Sosial: Kajian Sosiolinguistik di Kota Surakarta. Jurnal Kajian Linguistik dan Sastra, 18 (34). $1-15$.

Suhendar, N. 2016. Ragam Bahasa di Kecamatan Pakisjaya Kabupaten Karawang (KAJIAN Sosiolinguistik), Jurnal LOKABASA, 7 (1). 53-61.

Soyomukti, Nurani. 2013. Komunikasi Politik: Kudeta Politik Media, Analisa Komunikasi Rakyat dan Penguasa. Malang: Intrans Publishing, (online). (https://books.google.co.id/books?id=4w hJngEACAAJ\&dq=Komunikasi+Politik: +Kudeta+Politik+Media,+Analisa+Kom unikasi+Rakyat+dan+Penguasa\&hl=id\& $\underline{\mathrm{sa}=X \& v e d=0 a h U K E w i S h c O p k \_n o A h W}$ E7XMBHTviDVcQ6AEIKDAA, diakses 21 april 2020)

Susilawati, E \& Yusuf. 2017. Variasi Bahasa dalam Novel Peyempuan Karya @ Peyem. Jurnal Bastra, 1 (4). 14.

Tressyalina. 2015. Pertanyaan Tertutup sebagai Perwujudan Penggunaan Tindak Tutur Langsung dalam Gelar Wicara di Televisi Indonesia. Jurnal Logat, 2 (2). 91-96.

Tarigan, H. G. 2009. Pengajaran Wacana. Bandung: Angkasa.
Trans7 Official. 2017. Kisah Demian Aditya Perform di Amerika, (online), (https://www.youtube.com/watch?v=fIIj KJX_Tnc\&t=7s, diakses 12 april 2020). Trans 7 Official. 2020. Apa kata Pengamat Pendidikan tentang Belajar di Rumah, (online), (https://www.youtube.com/watch?v=Gs OUJoKXKFA\& $\mathrm{t}=5 \mathrm{~s}$, diakses 12 april 2020).

Trans7 Official. 2018. Rudy Salim, Pebisnis Muda Berpenghasilan Miliaran Rupiah (online), (https://www.youtube.com/watch?v=Dzx UieU0hz0, diakses 31 maret 2020).

Trans7 Official. 2019. Billy, Anak Penjual Kue Asal Papua yang Jadi Staf Khusus Presiden, (online), (https://www.youtube.com/watch?v=Po9 -9ibQylU, diakses 12 april 2020).

Trans7 Official. 2018. Najwa Shihab: Tamu Istimewa, (online), (https://www.youtube.com/watch?v=Po9 -9ibQylU, diakses 31 maret 2020).

Trans7 Official. 2018. Viral, Anak Majikan Memberangkatkan Umroh Pengasuhnya, (online), (https://www.youtube.com/watch?v=dy2 Vc0DGCeI, diakses 12 april 2020).

Trans7 Official. 2020. Tri Adinata, Guru Viral Mengajar Gitar dengan Energik, (online),(https://www.youtube.com/watc $\underline{\mathrm{h} ? \mathrm{v}=\mathrm{nkElSDiu}-\mathrm{uE} \& \mathrm{t}=6 \mathrm{~s}}, \quad$ diakses 31 maret 2020). 